Original Research

\title{
Konstruksi Portofolio Optimal Saham-Saham LQ45 Tahun 2019 di Bursa Efek Indonesia
}

\author{
Wibisono Hardjopranoto ${ }^{1 *}$ \\ ${ }^{1}$ Jurusan Manajemen, Fakultas Bisnis dan Ekonomika, Universitas Surabaya, Raya Kalirungkut Surabaya, \\ 60293-Indonesia \\ * corresponding author: wibisono@staff.ubaya.ac.id
}

\begin{abstract}
The ideal investment objective is to build an optimal investment portfolio. An investment portfolio that is able to provide maximum return at a certain level of risk. William Sharpe's (1963) Single Index Model (SIM) is a model with simple application, especially when compared to the Markowitz model (1952), mainly because of the consideration of the number of input variables. A simple SIM explains the relationship between market returns $(\mathrm{rm})$ as an independent variable and returns on securities, ri with variations in the risk as the slope characteristic line, Bi. The main limitation of MIS is that the risk in investing is represented only by changes in the index that are representative of the market. Using SIM, this study will describe the optimal portfolio construction by selecting LQ45 stocks on the Indonesia Stock Exchange (IDX) in 2019. The implementation of the SIM resulted in 19 LQ45 stocks selected from 45 stocks as optimal portfolio "members", along with the composition the weighting of the investment value starts from the highest weight to the lowest weight. Because using a single index in measuring risk, the application of SIM is aware of its various weaknesses and must be wise in choosing the index as the market. However, the application of SIM can provide valuable lessons for investment management.
\end{abstract}

Keywords: Portfolio Analysis, Optimal Portfolio, Risk Characteristic Line, Single Index Model

Abstrak-Tujuan investasi yang ideal adalah membangun portofolio investasi yang optimal. Portofolio investasi yang mampu memberikan imbal hasil (return) maksimal pada tingkat risiko tertentu. Single Index Model (SIM) William Sharpe (1963) merupakan model yang aplikasinya sederhana, terutama jika dibandingkan dengan model Markowitz (1952), terutama karena pertimbangan jumlah variabel masukannya. SIM secara sederhana menjelaskan hubungan antara imbal hasil pasar (market return, $\mathrm{r}_{\mathrm{m}}$ ) sebagai variable bebas dengan imbal hasil sekuritas, $r_{i}$ dengan variasi perubahan risiko berupa slope characteristic line, $\beta_{i}$. Keterbatasan utama SIM adalah karena risiko berinvestasi hanya diwakili satu-satunya oleh perubahan-perubahan indeks tertentu mewakili pasar. Dengan menggunakan SIM, penelitian ini hendak menggambarkan bangunan portofolio optimal dengan memilih sahamsaham LQ45 di Bursa Efek Indonesia (BEI) tahun 2019. Penerapan SIM dimaksud menghasilkan 19 saham LQ45 yang terpilih dari 45 saham sebagai "anggota" portofolio optimal, berikut komposisi pembobotan nilai investasinya mulai dari bobot yang tertinggi ke bobot terendah. Karena menggunakan indeks tunggal dalam mengukur risiko, penerapan SIM selain harus menyadari berbagai kelemahannya juga harus benar-benar bijak dalam memilih indeks sebagai pasarnya. Bagaimanapun, penerapan SIM mampu memberikan pelajaran yang sangat berharga bagi manajemen investasi.

Kata kunci: Portfolio Analysis, Optimal Portfolio, Risk Characteristic Line, Single Index Model

PENDAHULUAN

Keputusan investasi ideal, jika dipilih rencana investasi menghasilkan konstruksi portofolio investasi yang optimal. Tulisan Sharpe (1963) di Management Science berjudul: " $A$ Simplified Model For Portfolio Analysis" merupakan temuan ilmiah yang menarik. Model ini yang kemudian populer dikenal sebagai Single Index Model (SIM) mengetengahkan bagaimana cara mengonstruksi portofolio yang optimal. SIM bersifat sederhana dan pada kesederhanaan tersebut terletak keunggulannya karena SIM memberikan pelajaran tentang bagaimana cara memilih saham-saham anggota dari portofolio optimal yang menjanjikan nilai intrinsik atau nilai tambah ekonomi investasi yang maksimal.

SIM merupakan "koreksi kelemahan" dari model Markowitz (1952) yang penerapannya lebih kompleks karena membutuhkan estimasi yang banyak sekali. Bodie, Kane, Marcus, Mohanty, (2009) mengetengahkan dua alasan penting: Pertama, model membutuhkan estimasi parameter dalam jumlah besar untuk mengisi matriks kovarians; Kedua, model tersebut tidak memberikan pedoman apa pun untuk peramalan premi risiko sekuritas yang penting dalam rangka membangun efficient frontier dari aset berisiko (risky assets). Efficient frontier merupakan kombinasi imbal hasil dengan risiko dalam dua alternatif 
relasi: Pertama, berbagai kombinasi dari imbal hasil investasi tertinggi pada berbagai tingat risiko yang sama atau Kedua, berbagai kombinasi dari risiko terendah pada berbagai tingat imbal hasil investasi yang sama.

Studi ini memilih penerapan SIM pada saham-saham LQ45 di Bursa Efek Indonesia (BEI). LQ45 diluncurkan pada 13 Juli 1997 melengkapi 'Indeks Harga Saham Gabungan' (IHSG) dan masuk dalam jajaran teratas peringkat berdasarkan kapitalisasi pasar yang dilihat selama 12 bulan terakhir (May 2016). LQ45 merupakan indeks yang mengukur kinerja 45 saham yang memiliki likuiditas tinggi, berkapitalisasi pasar besar dan didukung oleh fundamental perusahaan yang baik. Secara keseluruhan terdapat 34 indeks saham, termasuk IHSG dan indeks saham sektoral (BEI 2019). Menurut Bloomberg, Indeks LQ45 merupakan a capitalization-weighted index of the 45 most heavily traded stocks on the Jakarta Stock Exchange. Salah satu kriteria yang menonjol dari Indeks LQ45 adalah bahwa saham-saham anggotanya dipilih di antara the most liquid traded di BEI.

Indeks saham merupakan ukuran statistik yang mencerminkan keseluruhan pergerakan harga atas sekumpulan saham yang dipilih berdasarkan kriteria dan metodologi tertentu serta dievaluasi secara berkala. Tujuan/ manfaat dari indeks saham antara lain: (1) Mengukur sentimen pasar; (2) Sebagai produk investasi pasif seperti Reksa Dana Indeks dan ETF Indeks serta produk turunan; (3) Benchmark bagi portofolio aktif; (4) Sebagai proksi dalam mengukur dan membuat model imbal hasil (return) investasi, risiko sistematis dan kinerja yang disesuaikan dengan risiko, (5) Proksi untuk kelas aset pada alokasi aset. PT Bursa Efek Indonesia (BEI) secara aktif terus melakukan inovasi dalam pengembangan dan penyediaan indeks saham yang dapat digunakan oleh seluruh pelaku pasar modal baik bekerja sama dengan pihak lain maupun tidak. Buku indeks "IDX Stock Index Handbook" berisikan gambaran ringkas dan padat mengenai indeks-indeks yang disediakan oleh BEI (BEI 2019).

Penelitian ini bertujuan: (1) Menerapkan Single Index Model Sharpe secara empiris dalam rangka mengonstruksi portofolio optimal pada saham-saham LQ45 untuk tahun 2019; (2) Menggambarkan konstruksi komposisi portofolio optimal secara hipotetis (ex-post) pada saham-saham LQ45 untuk tahun 2019; (3) Memeringkat saham-saham LQ45 disertai bobot masing-masing saham berdasarkan tingkatan perolehan imbal hasil sehingga dapat dipertimbangkan sebagai saham (aset) yang layak dipilih untuk dimasukkan dalam portofolio investor dalam rangka melakukan pengelolaan investasi.

\section{Singel Index Model}

Markowitz (1952) merupakan perintis analisis portofolio. Pendekatan yang dilakukannya adalah bahwa pada dasarnya adalah penghindaran risiko. Para investor biasanya berperilaku rasional, untuk menerima risiko tambahan tertentu mereka menuntut imbal hasil tambahan yang lebih besar. Menurut Markowitz (1952) risiko aset berisiko (risky asset) ditentukan oleh deviasi terhadap rata-rata imbal hasilnya. Dari angka deviasi itulah kemudian didapatkan varians (variance) dan deviasi standar (standard deviation). Pada portofolio yang merupakan gabungan dari beberapa aset, selain varians harus juga dikalkulasi kovarians (covariance). Kovarians dua aset A dan B pada hakikatnya merupakan 'hasil kali dari koefisien korelasi $A B$ dengan deviasi standar keduanya $\left(\operatorname{Covr}_{A} r_{B}=\operatorname{Corrr}_{A} r_{B} \cdot \sigma_{A} . \sigma_{B}\right)$. Untuk dua aset, perhitungan akan dengan mudah dapat dilakukan, tetapi jika portofolio terdiri atas beberapa aset perhitungan akan menjadi lebih rumit. Semakin banyak jenis aset dalam portofolio akan semakin rumit perhitungannya.

Singe Index Model (SIM) merupakan model 'penentuan harga aset sederhana' (simple asset pricing) yang perhitungannya lebih sederhana. SIM oleh Sharpe (1963) dikatakan sebagai kandidat yang menarik untuk aplikasi praktis awal dari teknik Markowitz dan tidak disangsikan penerapannya berbiaya sangat rendah. Model tersebut dibangun untuk mengukur risiko dan imbal hasil saham yang terkonstruksi dalam sebuah portofolio investasi. Model ini meletakkan 
pasar modal (indeks) sebagai satu-satunya faktor/ peubah/ variabel yang menentukan imbal hasil saham. Model ini mengusulkan bahwa hubungan antara setiap pasangan sekuritas dapat secara tidak langsung diukur dengan membandingkan sekuritas masing-masing dengan faktor umum 'indeks kinerja pasar' yang dibagi di antara semua sekuritas. Akibatnya, model dapat mengurangi beban persyaratan input besar dan perhitungan sulit dalam pengaturan meanvariance-Markowitz (Sharpe, 1963). Model ini hanya membutuhkan input data $(3 n+2)$ yaitu:

1. Estimasi Alpha $(\alpha)$ dan Beta $(\beta)$ untuk setiap sekuritas,

2. Estimasi risiko tidak sistematis $\left(\sigma_{e_{i}}^{2}\right)$ untuk setiap sekuritas,

3. Estimasi untuk 'imbal hasil yang diharapkan' pada indeks pasar (average market return) dan

4. Estimasi varians dari imbal hasil indeks pasar $\left(\sigma_{m}^{2}\right)$.

\section{Keunggulan SIM}

Keunggulan utama SIM adalah kesederhanaannya, terutama jika dibandingkan dengan Full-Covariance Markowitz model. Untuk portofolio dengan $n=5$ misalnya, data input yang dibutuhkan berjumlah $3(5)+2=17$. Jika analis memiliki $n$ sekuritas terpilih, maka diperlukan estimasi $(3 n+2)$ [mis. $\alpha_{i}, \beta_{i}, \sigma_{\text {ei }}^{2}$ untuk setiap sekuritas]; di sisi lain, model Markowitz membutuhkan perkiraan $\mathrm{n}(\mathrm{n}+3)=40$ [mis. $r_{i}$ dan $\sigma^{2}{ }_{i}$ untuk setiap sekuritas dan $\frac{n(n-1)}{2}$ kovarians.

SIM menyediakan sebuah estimasi terhadap imbal hasil sekuritas serta imbal hasil indeks. SIM merupakan metode yang penting dan mudah digunakan untuk menghitung portofolio optimal (Chauhan 2014). Sharpe menyederhanakan banyak perhitungan dan rumit untuk konstruksi portofolio optimal seperti yang disyaratkan dalam model Markowitz (Nalini 2014). Model Sharpe menimbulkan biaya modal harian yang lebih rendah sesuai dengan penalti Basel Capital Accord (McAleer \& Veiga 2008).

SIM menyederhanakan teknik komputasi yang diperlukan untuk menyelesaikan masalah. Semua input di atas dapat diperkirakan berdasarkan analisis historis dan/ atau evaluasi yang bersifat judgmental (yaitu analisis ex-post dan/ atau ex-ante).

- Imbal hasil yang diharapkan (IHD) masing-masing sekuritas misalnya:

$E\left(r_{i}\right)=\alpha_{i}+\beta_{i} E\left(r_{m}\right)$.

- Varians imbal hasil pada setiap sekuritas yaitu:

$\operatorname{Var}\left(r_{i}\right)=\beta_{i}^{2} E\left(r_{m}\right)+\operatorname{Var}\left(e_{i}\right)$, dan

- Kovarians imbal hasil antara setiap pasangan sekuritas yaitu:

$\operatorname{Cov}\left(r_{i} r_{j}\right)=\beta_{i} \beta_{j} \operatorname{Var}\left(r_{m}\right)$

SIM sangat bermanfaat dalam membangun portofolio optimal bagi investor dengan menganalisis logika di balik inklusi atau pengecualian sekuritas dalam portofolio dengan bobot masing-masing. Sharpe menemukan bahwa ada kesamaan yang cukup besar antara portofolio efisien yang dihasilkan oleh SIM dan model Markowitz. SIM berkinerja cukup baik (Elton et al. 1978, Benari 1988). SIM menyederhanakan banyak persyaratan input dan berkinerja baik, SIM mewakili kemajuan praktis yang lebih besar dalam analisis portofolio (Sinaee \& Moradi 2010). Tidak dapat disangkal, bahwa SIM merupakan model yang terbaik bagi pembelajar teori portofolio dan investor/analis investasi.

\section{Kelemahan SIM}

Salah satu keterbatasan paling penting SIM adalah bahwa model tersebut bercorak statis dan hanya dapat diterapkan dalam rentang waktu yang sangat terbatas sehingga seiring berjalannya waktu SIM tidak mempertimbangkan ketidakpastian di pasar; padahal, akibat perubahan-perubahan yang eskalatif, pasar berisiko dan mempunyai ketidakpastian, 
cenderung berubah secara dinamis seiring berjalannya waktu. SIM menyediakan portofolio optimal pada "satu titik (periode) waktu" saja tanpa mempertimbangkan sifat dinamis pasar. SIM juga mengasumsikan bahwa harga saham bergerak bersama hanya karena pergerakannya dengan pasar.

Banyak peneliti telah mengidentifikasi bahwa ada pengaruh di luar bisnis umum dan kondisi pasar, seperti faktor orientasi industri yang menyebabkan sekuritas bergerak bersama (Chandra 2009). Namun, bukti empiris menunjukkan bahwa model yang lebih rumit belum dalam posisi untuk mengungguli SIM dalam hal kemampuannya untuk memprediksi kovarians ex-ante antara imbal hasil sekuritas (Reilly \& Brown 2006).

\section{Asumsi SIM}

SIM mengasumsikan bahwa hanya ada satu faktor ekonomi-makro yang menjadi penyebab risiko sistematis (systematic risk) dan dengan demikian berpengaruh kepada imbal hasil saham. Faktor ini diwakili oleh tingkat imbal hasil indeks pasar (index rate of return) $r_{m}$ dan pasar dimaksud dapat diwakili oleh berbagai indeks terpilih. Untuk pasar modal Indonesia, pasar yang memiliki reputasi, antara lain: IHSG sendiri, atau LQ45, IDX30, IDX80, KOMPAS100, BISNIS-27, PEFINDO25; atau jika di Amerika Serikat: S\&P 500 atau Dow Jones Industrial Average (DJIA).

Menurut SIM, imbal hasil setiap saham dapat didekomposisi menjadi the expected excess return masing-masing saham karena faktor spesifik perusahaan (firm-specific factors), biasanya dilambangkan dengan 'koefisien alfa' $(\alpha)$, imbal hasil akibat pengaruh ekonomimakro yang mempengaruhi pasar, dan peristiwa ekonomi-mikro yang tidak terduga yang hanya memengaruhi badan usaha. Koefisien alfa sendiri merupakan 'imbal hasil saham' (stock return) jika premi risiko pasar nol $\left(r_{m}-r_{f}=0\right)$.

Unsur 'premi risiko pasar' $\beta_{i}\left(r_{m}-r_{f}\right)$ mewakili pergerakan pasar yang perubahannya dimodifikasi oleh/ tergantung pada beta saham $\beta_{i}$; sementara $\varepsilon_{i}$ mewakili risiko tak-sistematis (unsystematic risk) sekuritas karena faktor spesifik badan usaha (firm-specific factors) atau yang juga dikenal sebagai idiosyncratic risk. Dengan demikian, unsystematic risk $\left(\sigma_{e_{i}}^{2}\right)$ dapat dihitung dari selisih antara variance yang mewakili risiko total, dengan systematic risk.

Rumusnya:

$$
\begin{aligned}
& \text { Unsystematic risk = Variance - Systematic risk } \\
& \sigma_{e_{i}}^{2}=\sigma_{i}^{2}-\beta_{i}^{2} \sigma_{m}^{2} \\
& \text { atau, } \\
& \text { Variance }=\text { Unsystematic risk + Systematic risk } \\
& \sigma_{i}^{2}=\sigma_{e_{i}}^{2}+\beta_{i}^{2} \sigma_{m}^{2}
\end{aligned}
$$

Peristiwa ekonomi-makro, seperti perubahan-perubahan: suku bunga, biaya tenaga kerja (labor cost), pertumbuhan produk domestik bruto (PDB), nilai tukar valuta asing menyebabkan risiko sistematis yang memengaruhi imbal hasil semua saham. Peristiwa khusus (lokal) yang terjadi di dalam badan usaha merupakan peristiwa ekonomi-mikro yang juga memengaruhi imbal hasil saham badan usaha tertentu yang bersangkutan. Beberapa contoh, seperti terjadinya kematian dari orang-orang kunci di jajaran manajemen atau penurunan credit rating badan usaha, yang akan memengaruhi imbal hasil saham. Risiko yang terakhir ini yang dapat diturunkan melalui tindakan diversifikasi.

SIM dibangun berdasarkan pada asumsi-asumsi berikut: (1) Semua investor memiliki ekspektasi yang homogeny; (2) Untuk mengestimasi risiko dan imbal hasil untuk setiap sekuritas digunakan periode holding seragam; (3) Pergerakan harga sekuritas dalam kaitannya dengan yang lain tidak tergantung terutama pada sifat kedua sekuritas itu saja tetapi dapat mencerminkan pengaruh yang lebih besar yang mungkin muncul sebagai akibat dari kondisi bisnis dan ekonomi secara umum; (4) Hubungan antar-sekuritas hanya terjadi melalui 
pengaruh individualnya bersama dengan beberapa indeks kegiatan bisnis dan ekonomi; (5) Indeks, di mana imbal hasil masing-masing sekuritas berkorelasi, kemungkinan merupakan proksi pasar sekuritas; (6) Random disturbance, $\mathrm{e}_{\mathrm{i}}$ memiliki expected value nol (0) dan varians terbatas dan tidak berkorelasi dengan imbal hasil portofolio pasar $\left(r_{m}\right)$ serta dengan error term $\left(e_{i}\right)$ untuk sekuritas lain manapun; (7) Sebagian besar saham memiliki kovarians positif karena mereka semua merespons mirip dengan faktor ekonomi makro; (8) Beberapa badan usaha lebih sensitif terhadap faktor-faktor ini daripada yang lain, dan varians spesifik badan usaha ini biasanya dilambangkan dengan beta $(\beta)$, yang mengukur variansnya dibandingkan dengan pasar untuk satu atau beberapa faktor ekonomi; (9) Kovarians antar-sekuritas merupakan hasil dari respons yang berbeda terhadap faktor-faktor ekonomi-makro. Oleh karena itu, kovarians setiap saham dapat ditemukan dengan mengalikan beta mereka dengan varians pasar.

SIM mengasumsikan bahwa begitu imbal hasil pasar dikurangi, imbal hasil sisanya yang tidak berkorelasi:

$$
E\left(\left(r_{i, t}-\beta_{i} m_{t}\right)\left(r_{k, t}-\beta_{k} m_{t}\right)\right)=0
$$

yang memberikan

$$
\operatorname{Cov}\left(r_{i}, r_{k}\right)=\beta_{i} \beta_{k} \sigma^{2}
$$

\section{Imbal hasil sekuritas}

Imbal hasil sekuritas dihitung dengan rumus:

$$
r_{i t}=\frac{P_{i t}}{P_{i t-1}}-1
$$

\section{Notasi:}

$r_{i t}$ : imbal hasil sekuritas 'i' pada waktu ' $\mathrm{t}$ '

$P_{i t}$ : Harga saham/ sekuritas ' $\mathrm{i}$ ' pada waktu ' $\mathrm{t}$ '

$P_{i t-1}$ : Harga saham/ sekuritas ' $\mathrm{i}$ ' pada waktu 't-1'

Menurut asumsi dan notasi di atas ditemukan bahwa imbal hasil terhadap sekuritas $r_{i}$ tergantung pada indeks pasar $r_{m}$ dan istilah random disturbance term $e_{i}$. Secara simbolis,

$$
r_{i}=f\left(r_{m}, e_{i}\right)
$$

Tabel statistik berikut disiapkan untuk menunjukkan perhitungan yang diperlukan untuk menentukan nilai $\alpha_{i}$ dan $\beta_{i}$ :

\section{Tabel 1}

Perhitungan Nilai $\alpha_{i}$ dan $\beta_{i}$

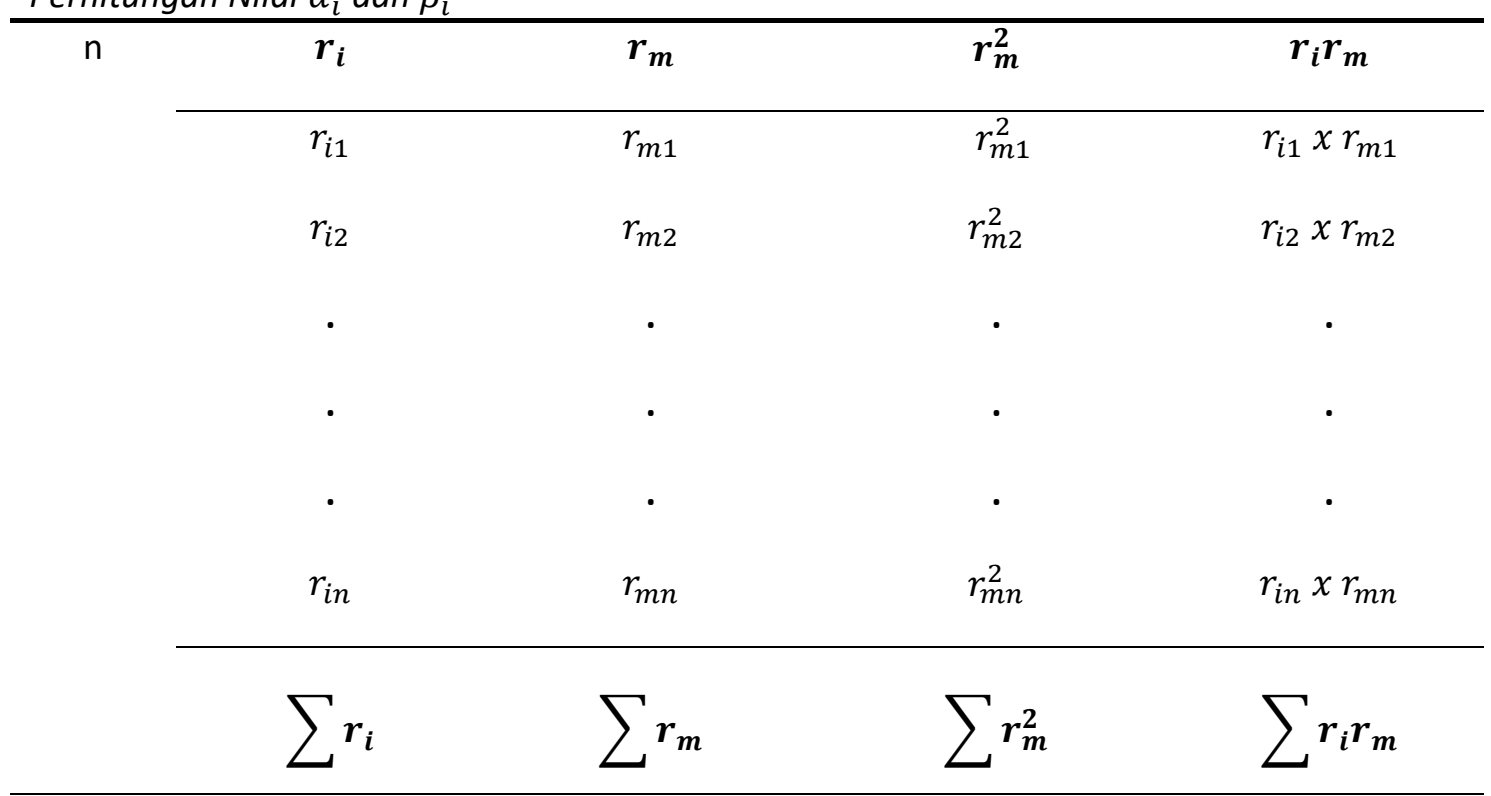


Dengan menempatkan angka-angka $\sum \boldsymbol{r}_{\boldsymbol{i}}, \sum \boldsymbol{r}_{\boldsymbol{m}}, \sum \boldsymbol{r}_{\boldsymbol{m}}^{2}$, dan $\sum \boldsymbol{r}_{\boldsymbol{i}} \boldsymbol{r}_{\boldsymbol{m}}$

Melakukan plot angka-angka: $\sum \boldsymbol{r}_{\boldsymbol{i}}, \sum \boldsymbol{r}_{\boldsymbol{m}}, \sum \boldsymbol{r}_{\boldsymbol{m}}^{2}$, dan $\sum \boldsymbol{r}_{\boldsymbol{i}} \boldsymbol{r}_{\boldsymbol{m}}$ diperoleh persamaan garis lurus antara imbal hasil sekuritas dan imbal hasil pasar,

$$
r_{i}=\alpha_{i}+\beta_{i} r_{m}
$$

Ini yang dikenal sebagai Single Index Model Sharpe yang kemudian dapat digambarkan sebagai berikut.

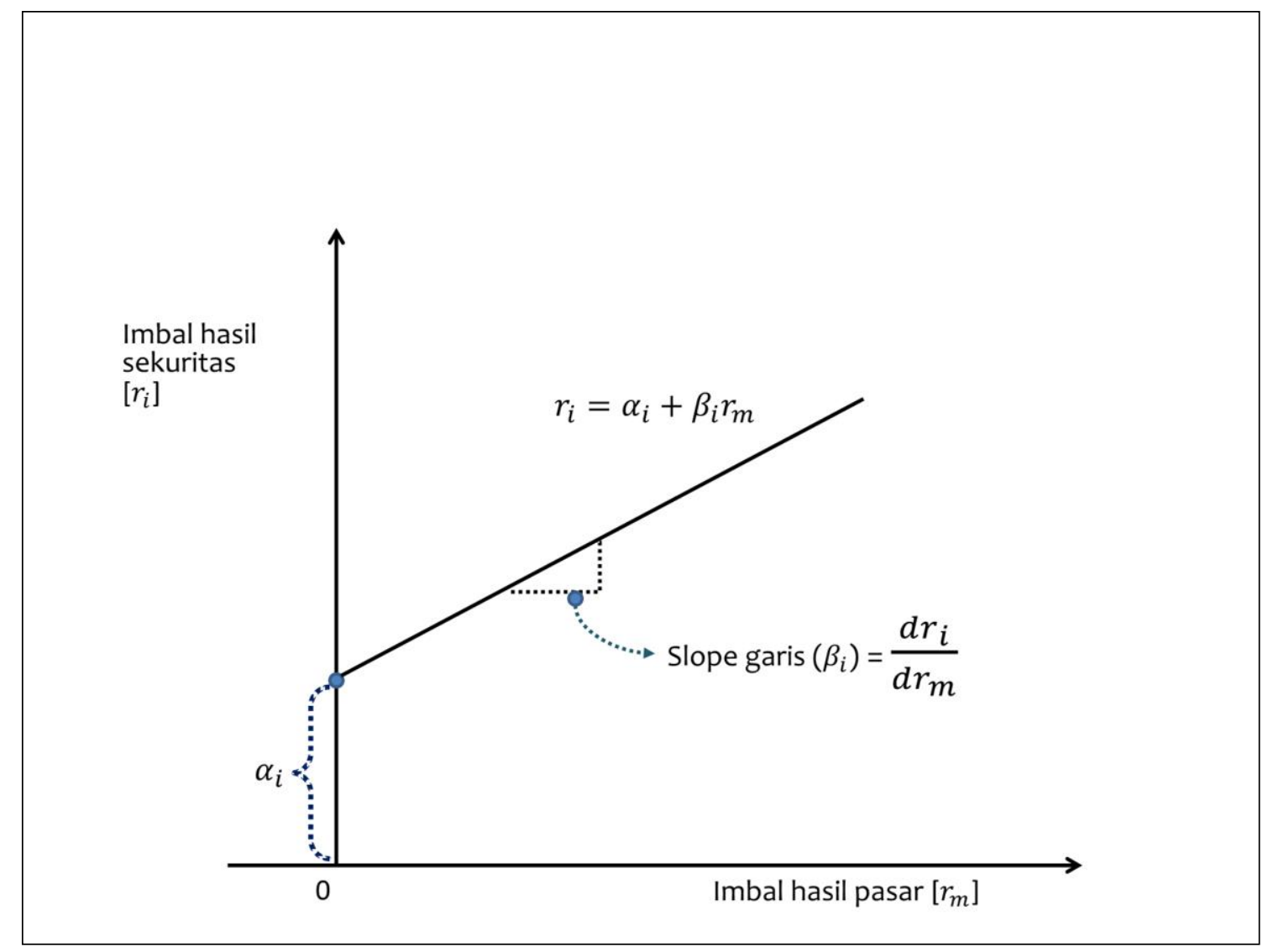

Gambar 1. Single Index Model Sharpe

Dari Gambar 1 tersebut tampak kesederhanaan SIM. Hanya terdapat dua komponen penting:

1. Komponen amung (unique part) alpha sekuritas $\left(\boldsymbol{\alpha}_{i}\right)$, dan

2. Komponen yang berkaitan dengan pasar $\boldsymbol{\beta}_{\boldsymbol{i}} \boldsymbol{r}_{\boldsymbol{m}}$

'Alpha' $(\alpha)$ ini memperlihatkan sebuah peristiwa mikro yang memengaruhi sekuritas secara individual yang bersifat spesifik/ khusus. Alpha menunjukkan nilai imbal hasil saham, $r_{i}$ ketika imbal hasil pasar, $r_{\mathrm{m}}=0$.

Bagian terkait pasar $\beta_{i} r_{m}$, di sisi lain, adalah peristiwa makro yang berbasis luas dan memengaruhi semua atau paling tidak, sebagian besar badan usaha. Beta $(\beta)$ merupakan derajat kemiringan (slope) garis, disebut sebagai 'Koefisien Beta'. Ini adalah ukuran kepekaan/ sensitivitas imbal hasil sekuritas terhadap pergerakan imbal hasil pasar (market return) secara keseluruhan. Komponen kedua ini menunjukkan "betapa berisikonya sebuah sekuritas, jika sekuritas tersebut disimpan dalam well-diversified portfolio". 


\section{Garis Karakteristik Risiko (The Risk Characteristic Line)}

Garis yang mewakili Model Indeks Tunggal Sharpe dikenal sebagai 'Garis Karakteristik Risiko'. Konsep garis karakteristik ini menyampaikan pesan tentang hakikat sekuritas dengan hanya mengamati nilai $\beta$-nya sebagai berikut (Lihat Gambar 2):

1. Sekuritas yang memiliki $\boldsymbol{\beta}>\mathbf{1}$ diklasifikasikan sebagai sekuritas agresif, karena naik lebih cepat dari di pasar 'bull' (yaitu pasar yang sedang naik) dan juga turun lebih cepat di pasar 'bear' (yaitu pasar yang sedang jatuh).

2. Sekuritas yang memiliki $\boldsymbol{\beta}<\mathbf{1}$ dikategorikan sebagai sekuritas defensif, karena imbal hasilnya berfluktuasi kurang dari variabilitas pasar secara keseluruhan.

3. Sekuritas yang memiliki $\boldsymbol{\beta}=\mathbf{1}$, adalah sekuritas netral, karena imbal hasilnya berfluktuasi pada tingkat yang sama dengan tingkat variabilitas imbal hasil pasar.

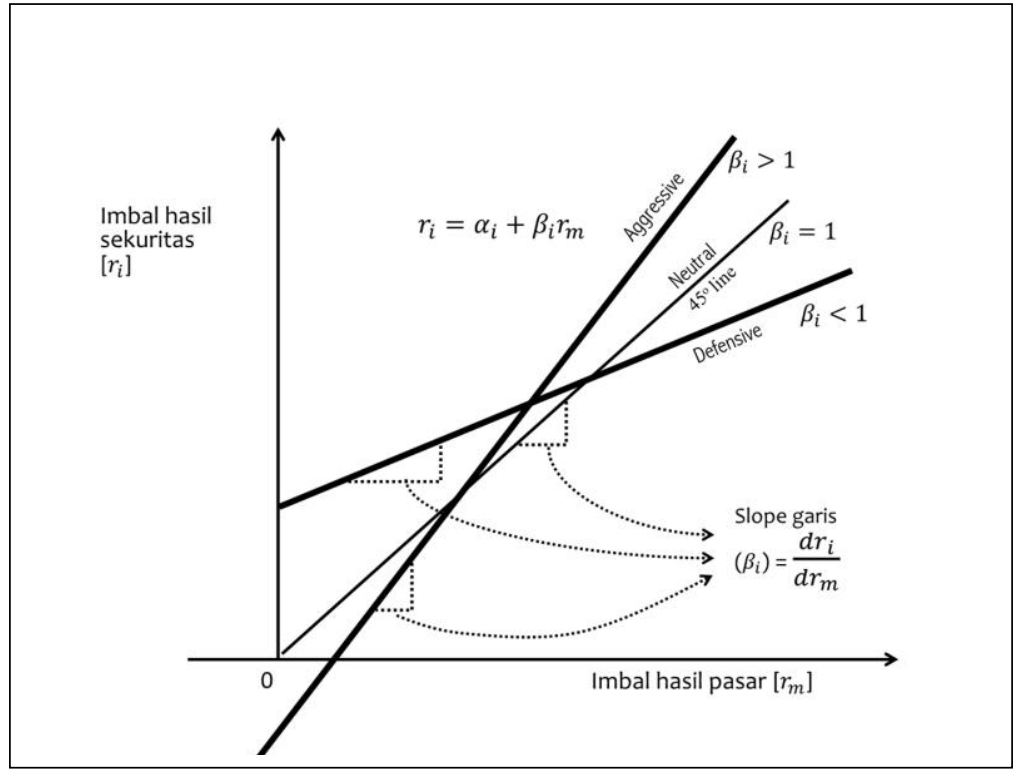

Gambar 2. Garis karakteristik risiko (The Risk Characteristic Line).

\section{Imbal Hasil Portofolio}

Untuk membangun hubungan antara imbal hasil portofolio dan imbal hasil pasar diperlukan untuk menentukan rata-rata tertimbang dari estimasi imbal hasil semua sekuritas dalam portofolio yang terdiri dari n-sekuritas, seperti berikut ini.

$$
\begin{aligned}
& \sum_{i=1}^{n} w_{i} r_{i}=\sum_{i=1}^{n} w_{i}\left(\alpha_{i}+\beta_{i} r_{m}+e_{i}\right) \\
& \text { atau, } \left.\sum_{i=1}^{n} w_{i} r_{i}=\sum_{i=1}^{n} w_{i} \alpha_{i}+r_{m} \sum_{i=1}^{n} w_{i} \beta_{i}+\sum_{i=1}^{n} w_{i} e_{i}\right) \\
& \text { atau, } r_{\rho}=\alpha_{\rho}+\beta_{\rho} r_{m}+e_{\rho} \\
& \text { di mana, } r_{\rho}=\sum_{i=1}^{n} w_{i} r_{i}, \alpha_{\rho}=\sum_{i=1}^{n} w_{i} \alpha_{i}, \beta_{\rho}=\sum_{i=1}^{n} w_{i} \beta_{i}, \text { dan } e_{\rho}=\sum_{i=1}^{n} w_{i} e_{i}
\end{aligned}
$$

Menurut asumsi klasik,

$e_{\rho}=\sum_{i=1}^{n} w_{i} e_{i}=0$, dan dengan demikian, $r_{\rho}=\alpha_{\rho}+\beta_{\rho} r_{m}$

Ini merupakan estimasi yang diperlukan atau regresi persamaan $r_{\rho}$ pada $r_{m}$, yang menetapkan hubungan antara imbal hasil portofolio $r_{\rho}$ dan imbal hasil pasar $r_{m}$.

Tabel statistik berikut disiapkan untuk memperlihatkan perhitungan yang diperlukan untuk menentukan $\alpha_{\rho}$ dan $\beta_{\rho}$ : 
Tabel 2

Perhitungan Nilai $\alpha_{p}$ dan $\beta_{p}$

$\mathrm{n}$

\begin{tabular}{ccccc}
$\boldsymbol{w}_{\boldsymbol{i}}$ & $\boldsymbol{\alpha}_{\boldsymbol{i}}$ & $\boldsymbol{w}_{\boldsymbol{i}} \boldsymbol{\alpha}_{\boldsymbol{i}}$ & $\boldsymbol{\beta}_{\boldsymbol{i}}$ & $\boldsymbol{w}_{\boldsymbol{i}} \boldsymbol{\beta}_{\boldsymbol{i}}$ \\
\hline$w_{1}$ & $\alpha_{1}$ & $w_{1} \alpha_{1}$ & $\beta_{1}$ & $w_{1} \beta_{1}$ \\
$w_{2}$ & $\alpha_{2}$ & $w_{2} \alpha_{2}$ & $\beta_{2}$ & $w_{2} \beta_{2}$ \\
$\cdot$ & $\cdot$ & $\cdot$ & $\cdot$ & $\cdot$ \\
$\cdot$ & $\cdot$ & $\cdot$ & $\cdot$ & $\cdot$ \\
$\cdot$ & $\cdot$ & $\cdot$ & $\cdot$ & $\cdot$ \\
$w_{n}$ & $\alpha_{n}$ & $w_{n} \alpha_{n}$ & $\beta_{n}$ & $w_{n} \beta_{n}$ \\
\hline$\sum_{i=1}^{n} w_{i}=1$ & --- & $\sum_{i=1}^{n} w_{i} \alpha_{i}$ & -- & $\sum_{i=1}^{n} w_{i} \beta_{i}$ \\
\hline \hline
\end{tabular}

Risiko Sekuritas

Dalam model indeks tunggal Sharpe, total risiko sekuritas, yang diukur dengan varians, dapat disimpulkan dengan menggunakan hubungan antara 'imbal hasil sekuritas' (security return) dan 'imbal hasil pasar' (market return) seperti di bawah:

$$
\begin{aligned}
& \operatorname{Var}\left(r_{i}\right)=\operatorname{Var}\left(\alpha_{i}+\beta_{i} r_{m}+e_{i}\right) \\
& \text { atau, } \operatorname{Var}\left(r_{i}\right)=\operatorname{Var}\left(\alpha_{i}\right)+\operatorname{Var}\left(\beta_{i} r_{m}\right)+\operatorname{Var}\left(e_{i}\right) \\
& \text { atau, } \operatorname{Var}\left(r_{i}\right)=\operatorname{Var}\left(\beta_{i} r_{m}\right)+\operatorname{Var}\left(e_{i}\right) \quad\left[\because \operatorname{Var}\left(\alpha_{i}\right)=0, \alpha_{i} \text { menjadi parameter }\right] \\
& \text { atau, } \sigma_{i}^{2}=\beta_{i}^{2} \sigma_{m}^{2}+\sigma_{e_{i}}^{2}
\end{aligned}
$$

Notasi:

$\sigma_{i}^{2}$ : Varians total

$\beta_{i}^{2} \sigma_{m}^{2}$ : Varians yang dapat dijelaskan

$\sigma_{e_{i}}^{2}$ : Varians yang tidak dapat dijelaskan (error disturbance)

\section{METODE}

Konstruksi portofolio optimal adalah tugas yang mudah jika 'nilai tunggal' (single value) mampu menjelaskan saham-saham (sekuritas) yang manakah yang harus dimasukkannya dalam portofolio. Nilai tunggal ini ada dalam SIM-nya Sharpe di mana ditemukan sekuritas yang terkait langsung dengan rasio 'ekses imbal hasil terhadap beta' (excess return to beta, ERB), $\frac{r_{i}-r_{f}}{\beta_{i}}$. Ini semata-mata merupakan fungsi dari ekses rasio ERB (Fischer \& Jordan 1995). Jika sekuritas diperingkatkan berdasarkan ekses rasio ERB (dari tertinggi ke terendah), peringkat tersebut memberikan petunjuk/ indikator untuk memasukkan sekuritas dalam portofolio. Batas pemilihan sekuritas untuk membangun portofolio optimal tergantung pada tingkat cut off yang unik, C* sehingga semua sekuritas yang memiliki $\frac{r_{i}-r_{f}}{\beta_{i}} \geq C^{*}$ akan dimasukkan dan pada saat yang sama semua sekuritas yang memiliki $\frac{r_{i}-r_{f}}{\beta_{i}}<\mathrm{C}^{*}$ akan disisihkan.

Selain memilih pasar (indeks) dan periode amatan yang hendak distudi proses penelitian juga perlu memperhatikan interval waktu dalam menghitung imbal hasil sekuritas dan indeks. Dengan memilih periode amatan selama satu tahun, tahun 2019, penelitian ini memilih interval waktu dalam menghitung imbal hasil dengan mendasarkannya pada 'harga penutupan' (closing price) harian. Dengan demikian $N=244$, jumlah hari bursa selama tahun yang bersangkutan. Selain itu, juga dipertimbangkan bahwa di tahun 2019 tidak terjadi gejolak perkembangan bursa yang menonjol. 


\section{Langkah-Langkah Penerapan SIM Dalam Mengonstruksi Portofolio Optimal}

Langkah-langkahnya terdiri atas tiga langkah utama berikut ini.

1. Langkah persiapan berupa pengumpulan data secara on line. Langkah persiapaan dilakukan dengan mengakses situs 'yahoo finance' menghimpun data-data mentah berupa 'closing price' baik indeks LQ45 maupun masing-masing saham LQ45 secara individual. Hasilnya ditabulasikan untuk kemudian dilanjutkan dengan perhitunganperhitungan sesuai rumus-rumus acuannya. Baik tabulasi maupun perhitungan dalam rangka mengonstruksi portofolio optimal keduanya dilakukan dengan menggunakan 'kertas kerja' (spreadsheet) EXCEL.

2. Langkah berikutnya merupakan langkah-langkah perhitungan. Secara terinci, secara bertahap secara keseluruhan terdapat 12 langkah secara berurutan dengan tiap-tiap rumus yang digunakan, dan

3. Langkah ketiga, merupakan langkah ringkasan untuk memnggambarkan 'portofolio optimal' hasil pemrosesan dari langkah-langkah sebelumnya. Di tahap akhir ini kemudian dapat digambarkan beberapa indicator utama dari portofolio, berupa: rata-rata imbah hasil, risiko dalam dua besaran berupa varians dan deviasi standar, dan imbal hasil indeks LQ45 itu sendiri.

\section{Proses perhitungan}

Langkah 1. Menghitung imbal hasil harian Indeks LQ45 dan imbal hasil harian saham anggotanya

Imbal hasil harian Indeks LQ45, data closing price berada pada blok sel 'E3:E247' dihitung masing-masing data hariannya dengan rumus:

$$
I H_{d} L Q 45=\frac{C_{d}-C_{d-1}}{C_{d-1}}
$$

Notasi:

$I H_{d} L Q 45:$ Imbal hasil pasar (indeks) hari ' $\mathrm{d}$ '

$C_{d}$ : Closing price indeks LQ45 hari ' $\mathrm{d}$ '

$C_{d-1}$ : Closing price indeks LQ45 hari ' $\mathrm{d}-1$ '

Imbal hasil harian saham ' $\mathrm{i}$ ', data closing price ADRO berada pada blok sel 'F3:F247' dihitung masing-masing data hariannya dengan rumus:

$$
I H_{d_{i}}=\frac{C_{d_{i}}-C_{d_{i}-1}}{C_{d_{i}-1}}
$$

Notasi:

$I H_{d_{i}}$ : Imbal hasil sekuritas/ saham ' $i$ ' hari ' $d$ '

$C_{d_{i}}$ : Closing price saham ' $\mathrm{i}$ ' hari ' $\mathrm{d}$ '

$C_{d_{i}-1}$ : Closing price saham 'i' hari ' $\mathrm{d}-1$ '

\section{Catatan:}

Rate of return hasil perhitungan periode waktunya tergantung pada data yang diacu; jika data tersebut merupakan data harian, maka $r_{i}$ merupakan daily rate of return. Konsekuensinya, untuk menyeragamkan 'suku bunga bebas risiko, $R_{f}$ yang pada umumnya dinyatakan dalam annual rate of return harus dikonversikan dalam bentuk daily rate, dengan rumus:

$$
\text { daily } r_{i}=\left(1+\text { annual }_{i}\right)^{1 / 244}-1
$$

Sebagai alternatif, konversi juga dapat menggunakan bakuan jumlah hari dalam setahun bukan jumlah hari bursa actual dalam setahun seperti 244 hari untuk tahun 2019 tetapi 365 hari. Sehingga rumusnya menjadi:

$$
\text { daily } r_{i}=\left(1+\text { annual } r_{i}\right)^{1 / 365}-1
$$


Langkah 2. Menghitung varians imbal hasil harian Indeks LQ45 dan varians dan deviasi standar imbal hasil saham anggotanya

Varians imbal hasil harian Indeks LQ45 dihitung dengan rumus fungsi EXCEL:

Untuk data yang ada di Kolom 'E', nilai pada sel E265, fungsi EXCEL-nya:

Variance $r_{m}$, E265 = VAR(E3:E247)

Varians imbal hasil harian masing-masing saham dihitung dengan rumus fungsi EXCEL:

Untuk data yang ada di Kolom 'F', fungsi EXCEL-nya:

Variance $r_{i}$, F251 = VAR(F3:F247)

Deviasi standarnya untuk ADRO, sel F252:

Standard deviation $\mathrm{r}_{\mathrm{i}}, \mathbf{F 2 5 2}=\mathrm{FSQRT}(\mathbf{2 5 1})$

Langkah 3. Menghitung kovarians imbal hasil harian antara Indeks LQ45 $\left(r_{m}\right)$ dan imbal hasil saham anggotanya $\left(r_{i}\right)$

Kovarians $\left(r_{i}-r_{m}\right)$ untuk ADRO pada sel F253:

Covariance $\left(r_{i}-r_{m}\right)$, F253 =VARP(\$E3:\$E247;F3:F247)

Langkah 4. Menghitung koefisien korelasi imbal hasil harian antara Indeks LQ45 $\left(r_{m}\right)$ dan imbal hasil saham anggotanya $\left(r_{i}\right)$

Koefisien korelasi $\left(r_{i}-r_{m}\right)$ untuk ADRO pada sel F254:

Correlation coefficient $\left(r_{i}-r_{m}\right)$, F254 =CORREL(\$E3:\$E247;F3:F247)

Langkah 5. Menghitung beta imbal hasil harian antara Indeks LQ45 $\left(r_{m}\right)$ dan imbal hasil saham anggotanya $\left(r_{i}\right)$

Beta $\left(r_{i}-r_{m}\right)$ untuk ADRO pada sel F255:

Beta coefficient $\left(r_{i}-r_{m}\right), \mathbf{F 2 5 5}=+\mathbf{F} 253 / \mathbf{F 2 5 1}$

Mengingat kembali rumus koefisien beta:

$$
\beta_{i}=\frac{\operatorname{Cov}\left(r_{i} r_{m}\right)}{\operatorname{Var}\left(r_{m}\right)}
$$

Langkah 6. Menghitung Risiko Sistematis (Systematic Risk)

Risiko sistematis merupakan:

$$
\beta_{i}^{2} x \sigma_{m}^{2}
$$

Langkah 7. Menghitung Risiko Taksistematis (Unsystematic Risk)

Risiko taksistematis dihitung dengan rumus:

Unsystematic risk $\left(\sigma_{e_{i}}^{2}\right)=\operatorname{Variance}\left(r_{m}\right)-\operatorname{Systematic}$ Risk $\left(\beta_{i}^{2} x \sigma_{m}^{2}\right)$

Dengan demikian,

Variance $\left(r_{m}\right)=$ Explained variance $\left(\beta_{i}^{2} \sigma_{m}^{2}\right)+$ Unexplained variance $\left(\sigma_{e_{i}}^{2}\right)$.

Langkah 8. Menghitung Excess Return 
Excess Return $=r_{i}-r_{f}$

Catatan:

Karena $r_{i}$ dihitung dengan ber-basis daily return, maka $r_{f}$ yang ditentukan dengan mengacu pada BI 7-days Repo Rate sebesar 5,00\%, dengan rumus:

Daily return $=(1+\text { Ann. return })^{\frac{1}{244}}$

Keterangan: Angka 244 dalam rumus tersebut merupakan banyaknya hari bursa dalam tahun 2018 yang datanya digunakan untuk menghitung rata-rata imbal hasil saham maupun indeks LQ45.

Daily return $=(1+5,00 \%)^{\frac{1}{244}}=0,000200$

Langkah 9. Menghitung Excess Return to Beta (ERB)

Excess return to beta (ERB) masing-masing saham dihitung dengan rumus:

$E R B=\frac{r_{i}-r_{f}}{\beta_{i}}$

Notasi:

$r_{i}$ imbal hasil saham ke-i

$r_{f}$ : the risk free rate (misalnya, suku bunga BI 7-day Repo)

$\beta_{i}$ : risiko sistematis saham atau kepekaan (responsiveness) saham i terhadap pasar

ERB merupakan rasio antara 'surplus imbal hasil' (excess return) $r_{i}-r_{f}$ dengan risiko sistematis saham $\beta_{i}$ yang bersangkutan. Jadi, ERB mengukur besarnya excess return per setiap unit risko sistematis saham (beta-nya).

Langkah 10. Menghitung cutoff rate $\mathrm{C}_{\mathrm{i}}$

Untuk masing-masing sekuritas dihitung $\mathrm{C}_{\mathrm{i}}$ dengan menggunakan rumus:

$$
C_{i}=\frac{\sigma_{m}^{2} \sum_{i=1}^{j} \frac{\left(r_{i}-r_{f}\right)}{\sigma_{e_{i}}^{2}} x \beta_{i}}{1+\sigma_{m}^{2} \sum_{i=1}^{j}\left(\frac{\left(r_{i}-r_{f}\right)}{\sigma_{e_{i}}^{2}}\right)}
$$

Notasi:

$\sigma_{m}^{2}:$ Varians pasar (indeks)

$\sigma_{e i}^{2}$ : Varians acak (random) dari saham yang tidak berhubungan dengan pergerakan indeks pasar (error, ukuran unsystematic risk saham)

$\beta_{i}$ : Beta saham

$\bar{r}_{i}$ : Imbal hasil saham (stock return) $\mathrm{i}$

Langkah 11. Menemukan $C_{i}$ optimum $\left(C^{*}\right)$ dan Memisahkan Saham untuk Dimasukkan ke dalam Portofolio Optimal.

$C_{i}$ optimum $\left(C^{*}\right)$ digunakan sebagai cut off hingga semua sekuritas yang dikaji mempunyai ERB di atas $C^{*}\left(\frac{r_{i}-r_{f}}{\beta_{i}} \geq C^{*}\right)$ dapat dipisahkan dari ERB yang lebih kecil daripada $C^{*}$ $\left(\frac{r_{i}-r_{f}}{\beta_{i}}<C^{*}\right)$. Selanjutnya sekuritas-sekuritas yang mempunyai $\frac{r_{i}-r_{f}}{\beta_{i}} \geq C^{*}$ dimasukkan ke dalam portofolio optimal. Proses ini dapat dilakukan dengan memanfaat-kan fungsi 'data sort' EXCEL dan hasilnya secara otomatis menampilkan beberapa saham/ sekuritas yang $\geq C^{*}$. 
Langkah 12. Menentukan Bobot $\left(\mathrm{W}_{\mathrm{i}}\right)$ Masing-Masing Saham

Portofolio optimal dibentuk dengan menghitung proporsi investasi dalam setiap sekuritas termasuk dalam portofolio. Titik akan dipilih sebagai titik potong (cut off point) setelah mana nilai kumulatif $C_{i}$ mulai menurun. Sekuritas yang memiliki nilai $C_{i}$ lebih atau sama dengan cut off point $\left(\geq C_{i}\right)$ akan dipilih masuk dalam portofolio optimal.

Proporsi (bobot) investasi setiap sekuritas/ saham dihitung/ ditentukan dengan menggunakan rumus:

$$
\begin{aligned}
& w_{i}=\frac{Z_{i}}{\sum_{j=1}^{k} Z_{j}} \\
& \underline{\text { Notasi: }} \\
& Z_{i}=\frac{\beta_{i}}{\sigma_{e_{i}}^{2}}\left(\frac{r_{i}-r_{f}}{\beta_{i}}-C^{*}\right)
\end{aligned}
$$

$i: 1,2,3, \ldots$ k dari $n$ sekuritas yang ditelaah.

Perlu dicatat bahwa untuk menentukan berapa banyak berinvestasi dalam sekuritas, masing-masing varians residual setiap sekuritas, $\sigma_{e_{i}}^{2}$ memiliki peran besar.

$$
Z_{i}=\frac{\beta_{i}}{\sigma_{e i}^{2}}\left[\left(\frac{R_{i}-R_{f}}{\beta_{i}}\right)-C^{*}\right]
$$

Hasil perhitungan 'kertas kerja' EXCEL kemudian ditampilkan dalam beberapa tabel, yakni Tabel 3 (Hasil perhitungan dari langkah \#1 hingga \#9), Tabel 4 (Hasil proses sort berdasarkan ERB berikut cut off point pada $C^{*}$. Ini merupakan hasil perhitungan langkah \#10 dan \#11), Tabel 5 (Hasil pembobotan dari seluruh 19 saham terpilih yang masuk dalam konstruksi portofolio optimal), Tabel 6 (Ringkasan deskripsi portofolio optimal saham-saham LQ45).

Langkah-langkah tersebut digambarkan dalam bagan alur (flowchart) berikut.



Gambar 3. Bagan alur (flowchart) penerapan SIM. 
Tabel 3

Statistik Imbal Hasil, Varians, Deviasi Standar, Kovarians, Korelasi, Beta, Risiko Sistematik,

Risiko Tak-sistematis, dan ERB Saham-Saham LQ45 Tahun Bursa 2019

\begin{tabular}{|c|c|c|c|c|c|c|c|c|c|c|c|}
\hline No. & Kode & Daily ri & $\begin{array}{c}\text { Variance ri } \\
(\sigma 2 \mathrm{i})\end{array}$ & St. dev. ri & Cov. (ri, rm) & $\begin{array}{l}\text { Corr. (ri, } \\
\text { rm) }\end{array}$ & $\begin{array}{l}\text { Beta (ri- } \\
\text { rm) }\end{array}$ & $\begin{array}{l}\text { Syst. Risk } \\
\text { [B2xo2m] }\end{array}$ & $\begin{array}{l}\text { Unsy. Risk } \\
\text { (б2ei) }\end{array}$ & $\begin{array}{l}\text { Exc. return } \\
\text { (ri - rf) }\end{array}$ & ERB \\
\hline 1 & ADRO & 0,00134 & 0,00073 & 0,02703 & 0,00041 & 0,38 & 0,56 & 0,00005 & 0,00068 & 0,00114 & 0,00204 \\
\hline 2 & INDY & $(0,00043)$ & 0,00128 & 0,03576 & 0,00068 & 0,28 & 0,53 & 0,00005 & 0,00123 & $(0,00043)$ & $(0,00081)$ \\
\hline 3 & ITMG & $(0,00197)$ & 0,00064 & 0,02531 & 0,00036 & 0,23 & 0,57 & 0,00005 & 0,00059 & $(0,00197)$ & $(0,00346)$ \\
\hline 4 & PTBA & $(0,00167)$ & 0,00049 & 0,02204 & 0,00029 & 0,36 & 0,59 & 0,00005 & 0,00043 & $(0,00167)$ & $(0,00282)$ \\
\hline 5 & ELSA & $(0,00018)$ & 0,00041 & 0,02027 & 0,00025 & 0,30 & 0,61 & 0,00005 & 0,00036 & $(0,00018)$ & $(0,00030)$ \\
\hline 6 & MEDC & 0,00112 & 0,00075 & 0,02746 & 0,00042 & 0,28 & 0,56 & 0,00005 & 0,00070 & 0,00112 & 0,00201 \\
\hline 7 & ANTM & 0,00088 & 0,00074 & 0,02713 & 0,00041 & 0,39 & 0,56 & 0,00005 & 0,00069 & 0,00088 & 0,00158 \\
\hline 8 & INCO & 0,00093 & 0,00072 & 0,02680 & 0,00040 & 0,36 & 0,56 & 0,00005 & 0,00067 & 0,00093 & 0,00167 \\
\hline 9 & INTP & 0,00206 & 0,00445 & 0,06669 & 0,00226 & 0,18 & 0,51 & 0,00005 & 0,00440 & 0,00206 & 0,00405 \\
\hline 10 & SMGR & 0,00051 & 0,00065 & 0,02548 & 0,00037 & 0,46 & 0,57 & 0,00005 & 0,00060 & 0,00051 & 0,00090 \\
\hline 11 & WSBP & $(0,00077)$ & 0,00029 & 0,01708 & 0,00019 & 0,50 & 0,65 & 0,00006 & 0,00023 & $(0,00077)$ & $(0,00118)$ \\
\hline 12 & BRPT & 0,00543 & 0,00152 & 0,03905 & 0,00081 & 0,08 & 0,53 & 0,00005 & 0,00148 & 0,00543 & 0,01022 \\
\hline 13 & TPIA & 0,00244 & 0,00038 & 0,01949 & 0,00023 & 0,15 & 0,62 & 0,00006 & 0,00032 & 0,00244 & 0,00394 \\
\hline 14 & CPIN & 0,00028 & 0,00110 & 0,03323 & 0,00059 & 0,49 & 0,54 & 0,00005 & 0,00106 & 0,00028 & 0,00051 \\
\hline 15 & INKP & $(0,00090)$ & 0,00153 & 0,03914 & 0,00081 & 0,42 & 0,53 & 0,00005 & 0,00149 & $(0,00090)$ & $(0,00171)$ \\
\hline 16 & TKIM & 0,00054 & 0,00162 & 0,04030 & 0,00085 & 0,53 & 0,53 & 0,00005 & 0,00158 & 0,00054 & 0,00103 \\
\hline 17 & ASII & $(0,00055)$ & 0,00028 & 0,01675 & 0,00018 & 0,60 & 0,66 & 0,00006 & 0,00022 & $(0,00055)$ & $(0,00084)$ \\
\hline 18 & SRIL & $(0,00116)$ & 0,00017 & 0,01306 & 0,00013 & 0,19 & 0,76 & 0,00007 & 0,00010 & $(0,00116)$ & $(0,00152)$ \\
\hline 19 & ICBP & 0,00041 & 0,00025 & 0,01578 & 0,00017 & 0,32 & 0,68 & 0,00006 & 0,00019 & 0,00041 & 0,00061 \\
\hline 20 & INDF & 0,00050 & 0,00029 & 0,01717 & 0,00019 & 0,47 & 0,65 & 0,00006 & 0,00024 & 0,00050 & 0,00077 \\
\hline 21 & GGRM & $(0,00160)$ & 0,00053 & 0,02304 & 0,00031 & 0,36 & 0,58 & 0,00005 & 0,00048 & $(0,00160)$ & $(0,00274)$ \\
\hline 22 & HMSP & $(0,00216)$ & 0,00046 & 0,02147 & 0,00028 & 0,36 & 0,60 & 0,00005 & 0,00041 & $(0,00216)$ & $(0,00361)$ \\
\hline 23 & KLBF & 0,00038 & 0,00027 & 0,01637 & 0,00018 & 0,54 & 0,66 & 0,00006 & 0,00021 & 0,00038 & 0,00057 \\
\hline 24 & UNVR & $(0,00024)$ & 0,00034 & 0,01839 & 0,00021 & 0,43 & 0,63 & 0,00006 & 0,00028 & $(0,00024)$ & $(0,00038)$ \\
\hline 25 & BSDE & 0,00027 & 0,00054 & 0,02333 & 0,00032 & 0,45 & 0,58 & 0,00005 & 0,00049 & 0,00027 & 0,00047 \\
\hline 26 & PWON & $(0,00008)$ & 0,00054 & 0,02322 & 0,00031 & 0,52 & 0,58 & 0,00005 & 0,00049 & $(0,00008)$ & $(0,00013)$ \\
\hline 27 & $\mathrm{ADHI}$ & $(0,00116)$ & 0,00040 & 0,01992 & 0,00024 & 0,54 & 0,61 & 0,00005 & 0,00034 & $(0,00116)$ & $(0,00189)$ \\
\hline 28 & PTPP & $(0,00042)$ & 0,00069 & 0,02627 & 0,00039 & 0,49 & 0,56 & 0,00005 & 0,00064 & $(0,00042)$ & $(0,00075)$ \\
\hline 29 & WIKA & 0,00092 & 0,00063 & 0,02509 & 0,00036 & 0,53 & 0,57 & 0,00005 & 0,00058 & 0,00092 & 0,00163 \\
\hline 30 & WSKT & $(0,00044)$ & 0,00053 & 0,02294 & 0,00031 & 0,51 & 0,58 & 0,00005 & 0,00047 & $(0,00044)$ & $(0,00075)$ \\
\hline 31 & PGAS & 0,00093 & 0,00210 & 0,04579 & 0,00109 & 0,21 & 0,52 & 0,00005 & 0,00205 & 0,00093 & 0,00178 \\
\hline 32 & JSMR & 0,00116 & 0,00080 & 0,02825 & 0,00044 & 0,44 & 0,55 & 0,00005 & 0,00075 & 0,00116 & 0,00209 \\
\hline 33 & EXCL & 0,00221 & 0,00063 & 0,02500 & 0,00036 & 0,39 & 0,57 & 0,00005 & 0,00057 & 0,00221 & 0,00388 \\
\hline 34 & TLKM & 0,00068 & 0,00086 & 0,02937 & 0,00047 & 0,39 & 0,55 & 0,00005 & 0,00081 & 0,00068 & 0,00123 \\
\hline 35 & $\mathrm{BBCA}$ & 0,00109 & 0,00018 & 0,01352 & 0,00014 & 0,06 & 0,74 & 0,00007 & 0,00012 & 0,00109 & 0,00146 \\
\hline 36 & $\mathrm{BBNI}$ & $(0,00023)$ & 0,00040 & 0,02002 & 0,00024 & 0,58 & 0,61 & 0,00005 & 0,00035 & $(0,00023)$ & $(0,00038)$ \\
\hline 37 & BBRI & 0,00091 & 0,00020 & 0,01414 & 0,00014 & 0,71 & 0,72 & 0,00006 & 0,00014 & 0,00091 & 0,00126 \\
\hline 38 & BBTN & 0,00318 & 0,00950 & 0,09748 & 0,00478 & 0,18 & 0,50 & 0,00004 & 0,00946 & 0,00318 & 0,00631 \\
\hline 39 & BMRI & 0,00032 & 0,00027 & 0,01632 & 0,00018 & 0,70 & 0,66 & 0,00006 & 0,00021 & 0,00032 & 0,00049 \\
\hline 40 & AKRA & 0,00020 & 0,00098 & 0,03135 & 0,00053 & 0,17 & 0,54 & 0,00005 & 0,00093 & 0,00020 & 0,00036 \\
\hline 41 & UNTR & 0,00033 & 0,00285 & 0,05339 & 0,00146 & 0,24 & 0,51 & 0,00005 & 0,00280 & 0,00033 & 0,00065 \\
\hline 42 & ERAA & 0,00013 & 0,00193 & 0,04388 & 0,00100 & 0,32 & 0,52 & 0,00005 & 0,00188 & 0,00013 & 0,00025 \\
\hline 43 & LPPF & $(0,00058)$ & 0,00117 & 0,03427 & 0,00063 & 0,19 & 0,54 & 0,00005 & 0,00113 & $(0,00058)$ & $(0,00108)$ \\
\hline 44 & MNCN & 0,00413 & 0,00123 & 0,03500 & 0,00066 & 0,23 & 0,54 & 0,00005 & 0,00118 & 0,00413 & 0,00768 \\
\hline 45 & SCMA & $(0,00081)$ & 0,00068 & 0,02611 & 0,00038 & 0,36 & 0,56 & 0,00005 & 0,00063 & $(0,00081)$ & $(0,00143)$ \\
\hline
\end{tabular}

Sumber: Yahoo Finance.Com (2020), diolah.

Tabel 4

Hasil Sort Berdasarkan ERB Saham-Saham LQ45 Tahun Bursa 2019

\begin{tabular}{|c|c|c|c|c|c|c|c|c|c|c|}
\hline No. & Kode & Daily $r_{i}$ & $\operatorname{Var} r_{i}\left(\sigma_{i}^{2}\right)$ & $\begin{array}{c}\text { Dev. Std. } \\
r_{i}\end{array}$ & $\begin{array}{c}\text { Beta } \\
\left(r_{i}-r_{m}\right)\end{array}$ & $\begin{array}{l}\text { Unsyst. } \\
\text { Risk }\left(\sigma^{2}{ }_{\text {ei }}\right)\end{array}$ & $\begin{array}{c}\text { Exc return } \\
\left(r_{i}-r_{f}\right)\end{array}$ & ERB & $\begin{array}{c}\left(r_{i}-r_{f}\right) \\
/ \sigma^{2}{ }_{e i}\end{array}$ & $\frac{\left(r_{i}-r_{f}\right) \beta_{i}}{\sigma_{\rho i}^{2}}$ \\
\hline & $r_{m}$ LQ45 & 0,00017 & Annual $r_{f}$ & 0,05 & 26,35 & 0,04465 & 0,01776 & & 13,15627 & 7,65570 \\
\hline & $\operatorname{Var} r_{m}$ & 0,000089 & Daily $r_{f}$ & 0,000200 & & & & & & \\
\hline & Dev. Std. $r_{m}$ & 0,00944 & $C^{*}$ & 0,000682 & & & & & & \\
\hline 1 & BRPT & 0,00543 & 0,00152 & 0,03905 & 0,53 & 0,00148 & 0,00543 & 0,01022 & 3,67763 & 1,95512 \\
\hline 2 & MNCN & 0,00413 & 0,00123 & 0,03500 & 0,54 & 0,00118 & 0,00413 & 0,00768 & 3,50722 & 1,88478 \\
\hline 3 & BBTN & 0,00318 & 0,00950 & 0,09748 & 0,50 & 0,00946 & 0,00318 & 0,00631 & 0,33578 & 0,16886 \\
\hline 4 & INTP & 0,00206 & 0,00445 & 0,06669 & 0,51 & 0,00440 & 0,00206 & 0,00405 & 0,46782 & 0,23772 \\
\hline 5 & TPIA & 0,00244 & 0,00038 & 0,01949 & 0,62 & 0,00032 & 0,00244 & 0,00394 & 7,50228 & 4,63806 \\
\hline 6 & EXCL & 0,00221 & 0,00063 & 0,02500 & 0,57 & 0,00057 & 0,00221 & 0,00388 & 3,85419 & 2,19946 \\
\hline 7 & JSMR & 0,00116 & 0,00080 & 0,02825 & 0,55 & 0,00075 & 0,00116 & 0,00209 & 1,54342 & 0,85492 \\
\hline 8 & ADRO & 0,00134 & 0,00073 & 0,02703 & 0,56 & 0,00068 & 0,00114 & 0,00204 & 1,67262 & 0,93537 \\
\hline 9 & MEDC & 0,00112 & 0,00075 & 0,02746 & 0,56 & 0,00070 & 0,00112 & 0,00201 & 1,59075 & 0,88629 \\
\hline
\end{tabular}


https://doi.org/10.24123/soshum.v1i2.2866

\begin{tabular}{|c|c|c|c|c|c|c|c|c|c|c|}
\hline 10 & PGAS & 0,00093 & 0,00210 & 0,04579 & 0,52 & 0,00205 & 0,00093 & 0,00178 & 0,45194 & 0,23465 \\
\hline 11 & INCO & 0,00093 & 0,00072 & 0,02680 & 0,56 & 0,00067 & 0,00093 & 0,00167 & 1,39894 & 0,78342 \\
\hline 12 & WIKA & 0,00092 & 0,00063 & 0,02509 & 0,57 & 0,00058 & 0,00092 & 0,00163 & 1,59756 & 0,90860 \\
\hline 13 & ANTM & 0,00088 & 0,00074 & 0,02713 & 0,56 & 0,00069 & 0,00088 & 0,00158 & 1,28681 & 0,71862 \\
\hline 14 & $\mathrm{BBCA}$ & 0,00109 & 0,00018 & 0,01352 & 0,74 & 0,00012 & 0,00109 & 0,00146 & 9,32063 & 6,91781 \\
\hline 15 & BBRI & 0,00091 & 0,00020 & 0,01414 & 0,72 & 0,00014 & 0,00091 & 0,00126 & 6,72371 & 4,84695 \\
\hline 16 & TLKM & 0,00068 & 0,00086 & 0,02937 & 0,55 & 0,00081 & 0,00068 & 0,00123 & 0,83223 & 0,45731 \\
\hline 17 & TKIM & 0,00054 & 0,00162 & 0,04030 & 0,53 & 0,00158 & 0,00054 & 0,00103 & 0,34358 & 0,18049 \\
\hline 18 & SMGR & 0,00051 & 0,00065 & 0,02548 & 0,57 & 0,00060 & 0,00051 & 0,00090 & 0,84754 & 0,48003 \\
\hline 19 & INDF & 0,00050 & 0,00029 & 0,01717 & 0,65 & 0,00024 & 0,00050 & 0,00077 & 2,10265 & 1,36396 \\
\hline 20 & UNTR & 0,00033 & 0,00285 & 0,05339 & 0,51 & 0,00280 & 0,00033 & 0,00065 & 0,11891 & 0,06107 \\
\hline 21 & ICBP & 0,00041 & 0,00025 & 0,01578 & 0,68 & 0,00019 & 0,00041 & 0,00061 & 2,17853 & 1,47361 \\
\hline 22 & KLBF & 0,00038 & 0,00027 & 0,01637 & 0,66 & 0,00021 & 0,00038 & 0,00057 & 1,82541 & 1,21139 \\
\hline 23 & CPIN & 0,00028 & 0,00110 & 0,03323 & 0,54 & 0,00106 & 0,00028 & 0,00051 & 0,26156 & 0,14077 \\
\hline 24 & BMRI & 0,00032 & 0,00027 & 0,01632 & 0,66 & 0,00021 & 0,00032 & 0,00049 & 1,56657 & 1,04116 \\
\hline 25 & BSDE & 0,00027 & 0,00054 & 0,02333 & 0,58 & 0,00049 & 0,00027 & 0,00047 & 0,55041 & 0,31898 \\
\hline 26 & AKRA & 0,00020 & 0,00098 & 0,03135 & 0,54 & 0,00093 & 0,00020 & 0,00036 & 0,21150 & 0,11487 \\
\hline 27 & ERAA & 0,00013 & 0,00193 & 0,04388 & 0,52 & 0,00188 & 0,00013 & 0,00025 & 0,06876 & 0,03583 \\
\hline 28 & PWON & $(0,00008)$ & 0,00054 & 0,02322 & 0,58 & 0,00049 & $(0,00008)$ & $(0,00013)$ & $(0,15648)$ & $(0,09081)$ \\
\hline 29 & ELSA & $(0,00018)$ & 0,00041 & 0,02027 & 0,61 & 0,00036 & $(0,00018)$ & $(0,00030)$ & $(0,50233)$ & $(0,30447)$ \\
\hline 30 & $\mathrm{BBNI}$ & $(0,00023)$ & 0,00040 & 0,02002 & 0,61 & 0,00035 & $(0,00023)$ & $(0,00038)$ & $(0,66549)$ & $(0,40516)$ \\
\hline 31 & UNVR & $(0,00024)$ & 0,00034 & 0,01839 & 0,63 & 0,00028 & $(0,00024)$ & $(0,00038)$ & $(0,84835)$ & $(0,53388)$ \\
\hline 32 & WSKT & $(0,00044)$ & 0,00053 & 0,02294 & 0,58 & 0,00047 & $(0,00044)$ & $(0,00075)$ & $(0,91745)$ & $(0,53444)$ \\
\hline 33 & PTPP & $(0,00042)$ & 0,00069 & 0,02627 & 0,56 & 0,00064 & $(0,00042)$ & $(0,00075)$ & $(0,65654)$ & $(0,36924)$ \\
\hline 34 & INDY & $(0,00043)$ & 0,00128 & 0,03576 & 0,53 & 0,00123 & $(0,00043)$ & $(0,00081)$ & $(0,34865)$ & $(0,18575)$ \\
\hline 35 & ASII & $(0,00055)$ & 0,00028 & 0,01675 & 0,66 & 0,00022 & $(0,00055)$ & $(0,00084)$ & $(2,48437)$ & $(1,63125)$ \\
\hline 36 & LPPF & $(0,00058)$ & 0,00117 & 0,03427 & 0,54 & 0,00113 & $(0,00058)$ & $(0,00108)$ & $(0,51441)$ & $(0,27567)$ \\
\hline 37 & WSBP & $(0,00077)$ & 0,00029 & 0,01708 & 0,65 & 0,00023 & $(0,00077)$ & $(0,00118)$ & $(3,29120)$ & $(2,14257)$ \\
\hline 38 & SCMA & $(0,00081)$ & 0,00068 & 0,02611 & 0,56 & 0,00063 & $(0,00081)$ & $(0,00143)$ & $(1,28058)$ & $(0,72156)$ \\
\hline 39 & SRIL & $(0,00116)$ & 0,00017 & 0,01306 & 0,76 & 0,00010 & $(0,00116)$ & $(0,00152)$ & \#\#\#\#\#\#\#\# & $(8,54651)$ \\
\hline 40 & INKP & $(0,00090)$ & 0,00153 & 0,03914 & 0,53 & 0,00149 & $(0,00090)$ & $(0,00171)$ & $(0,60589)$ & $(0,31938)$ \\
\hline 41 & $\mathrm{ADHI}$ & $(0,00116)$ & 0,00040 & 0,01992 & 0,61 & 0,00034 & $(0,00116)$ & $(0,00189)$ & $(3,37277)$ & $(2,06048)$ \\
\hline 42 & GGRM & $(0,00160)$ & 0,00053 & 0,02304 & 0,58 & 0,00048 & $(0,00160)$ & $(0,00274)$ & $(3,33743)$ & $(1,94600)$ \\
\hline 43 & PTBA & $(0,00167)$ & 0,00049 & 0,02204 & 0,59 & 0,00043 & $(0,00167)$ & $(0,00282)$ & $(3,84730)$ & $(2,27408)$ \\
\hline 44 & ITMG & $(0,00197)$ & 0,00064 & 0,02531 & 0,57 & 0,00059 & $(0,00197)$ & $(0,00346)$ & $(3,33379)$ & $(1,89708)$ \\
\hline 45 & HMSP & $(0,00216)$ & 0,00046 & 0,02147 & 0,60 & 0,00041 & $(0,00216)$ & $(0,00361)$ & $(5,28491)$ & $(3,15605)$ \\
\hline
\end{tabular}

Sumber: Tabel No. 1, diolah.

\section{Tabel 5}

Hasil Pembobotan Berdasarkan Z, Positif Pembentuk Portofolio Optimal, Saham Saham LQ45 Tahun Bursa 2019

\begin{tabular}{|c|c|c|c|c|c|c|c|c|c|c|c|c|}
\hline No. & Kode & Daily $r_{i}$ & $\begin{array}{c}\text { Var. ri } \\
\left(\sigma^{2} \mathrm{i}\right)\end{array}$ & $\begin{array}{c}\text { Dev. Std. } \\
r_{i}\end{array}$ & $\begin{array}{c}\beta\left(r_{i^{-}}\right. \\
\left.r_{m}\right)\end{array}$ & $\left(\sigma^{2}{ }_{e i}\right)$ & $\left(r_{i}-r_{f}\right)$ & ERB & $\begin{array}{c}\left(r_{i}-r_{f}\right) \\
/ \sigma^{2}{ }_{e i}\end{array}$ & $\frac{\left(r_{i}-r_{f}\right) \beta_{i}}{\sigma_{o i}^{2}}$ & $Z_{i}$ & $W_{i}$ \\
\hline & Variance & & & & \multirow{6}{*}{26,35} & \multirow{6}{*}{0,04465} & \multirow{6}{*}{0,01776} & & \multirow{6}{*}{13,15} & \multirow{6}{*}{7,65570} & \multirow{6}{*}{261,5242} & \multirow{6}{*}{$100,00 \%$} \\
\hline & $r_{m}$ & 0,000089 & & & & & & & & & & \\
\hline & Dev. Std. & & & & & & & & & & & \\
\hline & $r_{m}$ & 0,00944 & LQ45 & 0,00017 & & & & & & & & \\
\hline & Annual $r_{f}$ & 0,05 & & & & & & & & & & \\
\hline & Daily $r_{f}$ & 0,000200 & & & & & & & & & & \\
\hline 1 & BRPT & 0,00543 & 0,00152 & 0,03905 & 0,53 & 0,00148 & 0,00543 & 0,01022 & 3,67763 & 1,95512 & 56,86869 & $21,75 \%$ \\
\hline 2 & MNCN & 0,00413 & 0,00123 & 0,03500 & 0,54 & 0,00118 & 0,00413 & 0,00768 & 3,50722 & 1,88478 & 42,19745 & $16,14 \%$ \\
\hline 3 & BBTN & 0,00318 & 0,00950 & 0,09748 & 0,50 & 0,00946 & 0,00318 & 0,00631 & 0,33578 & 0,16886 & 31,76354 & $12,15 \%$ \\
\hline 4 & INTP & 0,00206 & 0,00445 & 0,06669 & 0,51 & 0,00440 & 0,00206 & 0,00405 & 0,46782 & 0,23772 & 19,20898 & $7,35 \%$ \\
\hline 5 & TPIA & 0,00244 & 0,00038 & 0,01949 & 0,62 & 0,00032 & 0,00244 & 0,00394 & 7,50228 & 4,63806 & 22,59932 & $8,64 \%$ \\
\hline 6 & EXCL & 0,00221 & 0,00063 & 0,02500 & 0,57 & 0,00057 & 0,00221 & 0,00388 & 3,85419 & 2,19946 & 20,45446 & $7,82 \%$ \\
\hline 7 & JSMR & 0,00116 & 0,00080 & 0,02825 & 0,55 & 0,00075 & 0,00116 & 0,00209 & 1,54342 & 0,85492 & 8,72130 & $3,33 \%$ \\
\hline 8 & ADRO & 0,00134 & 0,00073 & 0,02703 & 0,56 & 0,00068 & 0,00114 & 0,00204 & 1,67262 & 0,93537 & 8,48780 & $3,25 \%$ \\
\hline 10 & PGAS & 0,00093 & 0,00210 & 0,04579 & 0,52 & 0,00205 & 0,00093 & 0,00178 & 0,45194 & 0,23465 & 6,42033 & $2,45 \%$ \\
\hline 11 & INCO & 0,00093 & 0,00072 & 0,02680 & 0,56 & 0,00067 & 0,00093 & 0,00167 & 1,39894 & 0,78342 & 6,19793 & $2,37 \%$ \\
\hline 12 & WIKA & 0,00092 & 0,00063 & 0,02509 & 0,57 & 0,00058 & 0,00092 & 0,00163 & 1,59756 & 0,90860 & 6,01780 & $2,30 \%$ \\
\hline 13 & ANTM & 0,00088 & 0,00074 & 0,02713 & 0,56 & 0,00069 & 0,00088 & 0,00158 & 1,28681 & 0,71862 & 5,63550 & $2,15 \%$ \\
\hline 14 & BBCA & 0,00109 & 0,00018 & 0,01352 & 0,74 & 0,00012 & 0,00109 & 0,00146 & 9,32063 & 6,91781 & 6,49938 & $2,49 \%$ \\
\hline 15 & BBRI & 0,00091 & 0,00020 & 0,01414 & 0,72 & 0,00014 & 0,00091 & 0,00126 & 6,72371 & 4,84695 & 4,70712 & $1,80 \%$ \\
\hline 16 & TLKM & 0,00068 & 0,00086 & 0,02937 & 0,55 & 0,00081 & 0,00068 & 0,00123 & 0,83223 & 0,45731 & 3,39304 & $1,30 \%$ \\
\hline 17 & TKIM & 0,00054 & 0,00162 & 0,04030 & 0,53 & 0,00158 & 0,00054 & 0,00103 & 0,34358 & 0,18049 & 2,06019 & $0,79 \%$ \\
\hline 18 & SMGR & 0,00051 & 0,00065 & 0,02548 & 0,57 & 0,00060 & 0,00051 & 0,00090 & 0,84754 & 0,48003 & 1,36126 & $0,52 \%$ \\
\hline 19 & INDF & 0,00050 & 0,00029 & 0,01717 & 0,65 & 0,00024 & 0,00050 & 0,00077 & 2,10265 & 1,36396 & 0,62654 & $0,24 \%$ \\
\hline 20 & UNTR & 0,00033 & 0,00285 & 0,05339 & 0,51 & 0,00280 & 0,00033 & 0,00065 & 0,11891 & 0,06107 & $(0,18709)$ & \\
\hline
\end{tabular}




\begin{tabular}{|c|c|c|c|c|c|c|c|c|c|c|c|}
\hline 21 & ICBP & 0,00041 & 0,00025 & 0,01578 & 0,68 & 0,00019 & 0,00041 & 0,00061 & 2,17853 & 1,47361 & $(0,56541)$ \\
\hline 22 & KLBF & 0,00038 & 0,00027 & 0,01637 & 0,66 & 0,00021 & 0,00038 & 0,00057 & 1,82541 & 1,21139 & $(0,79782)$ \\
\hline 23 & CPIN & 0,00028 & 0,00110 & 0,03323 & 0,54 & 0,00106 & 0,00028 & 0,00051 & 0,26156 & 0,14077 & $(1,01801)$ \\
\hline 24 & BMRI & 0,00032 & 0,00027 & 0,01632 & 0,66 & 0,00021 & 0,00032 & 0,00049 & 1,56657 & 1,04116 & $(1,44165)$ \\
\hline 26 & AKRA & 0,00020 & 0,00098 & 0,03135 & 0,54 & 0,00093 & 0,00020 & 0,00036 & 0,21150 & 0,11487 & $(1,93747)$ \\
\hline 27 & ERAA & 0,00013 & 0,00193 & 0,04388 & 0,52 & 0,00188 & 0,00013 & 0,00025 & 0,06876 & 0,03583 & $(2,53556)$ \\
\hline
\end{tabular}

Sumber: Tabel No. 2, diolah.

Tabel 6

Deskripsi Profil Portofolio Optimal Saham-Saham LQ45 Tahun Bursa 2019

\begin{tabular}{|c|c|c|c|c|}
\hline Average $r$ & turn LQ45 & $4,19 \%$ & Average $r_{p}$ & $126,53 \%$ \\
\hline Variance & & $2,20 \%$ & Variance $r_{p}$ & $2,13 \%$ \\
\hline Deviasi st & $n d a r r_{m}$ & $14,83 \%$ & Deviasi standar $r_{p}$ & $14,58 \%$ \\
\hline Annual $\mathrm{r}_{\mathrm{f}}$ & 7-days BI RR) & $5,00 \%$ & & \\
\hline No. & Kode & Annual $\mathrm{r}_{\mathrm{i}}$ & $W_{i}$ & $W_{i} \times r_{i}$ \\
\hline 1 & BRPT [34] & $275,18 \%$ & $21,75 \%$ & $59,84 \%$ \\
\hline 2 & MNCN [95] & $173,33 \%$ & $16,14 \%$ & $27,97 \%$ \\
\hline 3 & BBTN [81] & $116,75 \%$ & $12,15 \%$ & $14,18 \%$ \\
\hline 4 & TPIA [34] & $81,10 \%$ & $7,35 \%$ & $5,96 \%$ \\
\hline 5 & EXCL [73] & $71,50 \%$ & $8,64 \%$ & $6,18 \%$ \\
\hline 6 & INTP [31] & $65,20 \%$ & $7,82 \%$ & $5,10 \%$ \\
\hline 7 & JSMR [72] & $32,55 \%$ & $3,33 \%$ & $1,09 \%$ \\
\hline 8 & ADRO [21] & $38,58 \%$ & $3,25 \%$ & $1,25 \%$ \\
\hline 9 & MEDC [22] & $31,42 \%$ & $3,18 \%$ & $1,00 \%$ \\
\hline 10 & BBCA [81] & $30,31 \%$ & $2,45 \%$ & $0,74 \%$ \\
\hline 11 & INCO [23] & $25,60 \%$ & $2,37 \%$ & $0,61 \%$ \\
\hline 12 & PGAS [71] & $25,36 \%$ & $2,30 \%$ & $0,58 \%$ \\
\hline 13 & WIKA [62] & $25,29 \%$ & $2,15 \%$ & $0,54 \%$ \\
\hline 14 & BBRI [81] & $24,89 \%$ & $2,49 \%$ & $0,62 \%$ \\
\hline 15 & ANTM [23] & $24,04 \%$ & $1,80 \%$ & $0,43 \%$ \\
\hline 16 & TLKM [73] & $17,96 \%$ & $1,30 \%$ & $0,23 \%$ \\
\hline 17 & TKIM [38] & $14,13 \%$ & $0,79 \%$ & $0,11 \%$ \\
\hline 18 & SMGR [31] & $13,18 \%$ & $0,52 \%$ & $0,07 \%$ \\
\hline 19 & INDF [51] & $12,92 \%$ & $0,24 \%$ & $0,03 \%$ \\
\hline & & & $100,00 \%$ & $126,53 \%$ \\
\hline
\end{tabular}

Sumber: Tabel No. 2, diolah.

\section{Keterangan:}

Angka-angka di belakang 'Kode' saham merupakan kode sub-sektor/ industri, sbb.:

21 Coal mining

22 Crude petroleum \& NG products

23 Metal \& mineral mining

31 Cement

34 Chemicals

38 Pulp \& paper

51 Food \& beverages

62 Building construction

71 Energy

73 Telekomunikasi

81 Bank

95 Advertisement, printing \& media 


\section{SIMPULAN}

Dengan memanfaatkan lembar kerja (spreadsheet) Excel, berbagai perhitungan dalam rangka mengonstruksi portofolio optimal dapat dilakukan dengan sangat mudah dan cepat. Walaupun demikian penerapan SIM memerlukan ketelitian yang cukup tinggi, terutama dalam hal penggunaan berbagai rumus yang cukup beragam. Konstruksi portofolio optimal menggunakan Single index model (Sharpe 1963) pada saham-saham LQ45 selama setahun pada tahun bursa 2019 ini menghasilkan sebanyak 19 saham yang membentuk/mengonstruksi portofolio optimal (Lihat Tabel 4.). Studi tentang penerapan SIM ini merupakan pelajaran yang mendasar tentang analisis investasi. Tidak dapat disangkal, penerapan SIM merupakan studi yang nyata dan mendasar dalam rangka memahami dengan jelas bagaimana manajemen portofolio dilaksanakan.

Dari struktur komposisi portofolio optimal tersebut, bobot tertinggi, 21,75\% diduduki oleh saham BRPT (PT Barito Pasific Tbk) disusul di urutan berikutnya oleh saham-saham yang membentuk 'lima besar': MNCN, BBTN, TPIA dan EXCL. Portofolio optimal mempunyai imbal hasil rata-rata sebesar $126,53 \%$ dengan risiko yang terukur dalam deviasi standar, $14,58 \%$ (Varians, 2,13\%). Imbal hasil rata-rata tahun 2019 dari Indeks LQ45 sendiri terukur sebesar 4,19\%, dengan deviasi standar, 14,83\% (Varians, 2,20\%).

Dari sebaran sektoralnya, perigkat teratas saham-saham dalam portofolio optimal diduduki oleh: BRPT yang merupakan emiten yang bergerak di industri sektor 3, 'Basic industry and chemicals' subsektor 34, 'chemicals'; peringkat berikutnya, MNCN subsektor 95, 'advertisement, printing \& media'; BBTN subsektor 81, 'bank'; TPIA subsektor 34, 'chemicals'; dan di urutan kelima, EXCL subsektor 73, 'telecommunication'. Ini berarti bahwa sektor-sektor tersebut memberikan peluang usaha yang relatif lebih unggul dibandingkan dengan sektorsektor lainnya.

\section{Rekomendasi}

Hasil penelitian mengungkapkan bahwa: (1) Melalui pemanfaatan SIM, dapat dikonstruksi portofolio optimal yang terdiri dari 19 saham LQ45 2019 (Lihat Tabel 4.) yang terseleksi dari 45 saham LQ45 di BEI; (2) Dengan menggunakan analisis teknis dan berasumsi bahwa apa yang tergambar di tahun 2019 akan terus berlanjut di tahun-tahun berikutnya tanpa adanya perubahan-perubahan yang berarti, maka pemeringkatan 19 saham LQ45 tersebut layak digunakan sebagai acuan/bahan pertimbangan bagi investor dalam melakukan pengambilan keputusan investasi keuangan; (3) Dari analisis sektoral, tampak bahwa sektorsektor kimia, periklanan, percetakan dan media, perbankan dan telekomunikasi merupakan 'empat besar' sektor-sektor yang menguntungkan dalam berinvestasi; (4) Analis/investor dapat menggunakan informasi yang terdapat dalam portofolio optimal untuk digunakan sebagai masukan dalam analisis investasinya. Pilihan-pilihan misalnya, dapat saja dijatuhkan pada saham-saham tertentu dari 19 saham yang tampil dalam portofolio optimal tersebut, walaupun tidak harus diambil secara keseluruhan; (5) Bagi investor tertentu, saham-saham acuan tersebut juga dapat sekadar digunakan sebagai penguatan pembenar jika sebelumnya jenis saham-saham yang terdapat di dalam portofolio optimal tersebut telah dimiliki.

Penelitian lebih lanjut dapat dikembangkan dengan memperkaya variasi, terutama dalam: pemilihan batasan periode amatan studi, objek berupa pasar (indeks) maupun rancangan pemilihan interval waktu penilaian. Tidak hanya pada studi tentang indeks-indeks tertentu saja tetapi dapat pula dikembangkan studi komparatif antar-pasar/indeks.

Walaupun SIM bersifat sederhana, karena proses konstruksi portofolio optimal menggunakan rumus-rumus matematika dan statistika yang cukup banyak serta memiliki rangkaian proses yang cukup panjang, penerapannya memerlukan ketelitian yang tinggi. Perhatian/ketelitian yang cukup besar juga perlu ditujukan pada satuan pengukuran terutama dalam besaran persentase suku bunga. Penyeragaman sebaiknya dilakukan dalam bentuk suku bunga harian (daily interest rate) mengikuti data mentah yang diakses. Proses perhitungan sebaiknya dilakukan dalam angka-angka dalam bentuk desimal. 


\section{PUSTAKA ACUAN}

Benari, Y 1988, 'An asset allocation paradigm', Journal of Portfolio Management, Winter, pp. 22-26.

Bodie, Z, Kane, A, Marcus, AJ, \& Mohanty, P 2009, Investments, Tata McGraw Hill Education Private Limited, New Delhi.

Bursa Efek Indonesia (BEI) 2019, Indeks saham, dilihat 7 Mei 2020, https://www.idx.co.id/ produk/indeks/

Chandra, P 2009, Investment Analysis and Portfolio Management ( $3^{\text {rd }}$ ed), Tata McGraw-Hill Publishing Company Ltd, New Delhi.

Chauhan, AA 2014, 'A study on usage of Sharpe's Single Index Model in portfolio construction with reference to Cnx Nifty', Global Journal of Research Analysis, Vol. 3 No. 10, pp. 9294.

Elton, EJ et al. 1978, 'Optimum portfolio from simple ranking devices', Journal of Portfolio Management, Spring, pp. 15-19.

May, E 2016, 15 September, Mengenal LQ 45, dilihat 7 Mei 2020, https://finance.detik.com/bursa-dan-valas/d-3298411/mengenal-lq-45

McAleer, M \& Da Veiga, B 2008, 'Single -index and portfolio models for forecasting value- atrisk thresholds', Journal of Forecasting, Vol. 27, No. 3, p. 217.

Nalini, R 2014, 'Optimal portfolio construction using Sharpe's Single Index Model-A study of selected stocks from BSE', International Journal of Advanced Research in Management and Social Sciences, Vol. 3, No. 12, pp. 72-93.

Reilly, FK \& Brown, KC 2006, Investment analysis and portfolio management, CENGAGE Learning, New Delhi.

Sharpe, WF 1963, 'A simplified model for portfolio analysis', Management Science, Vol. 9, No. 2, pp. 277-293.

Sinaee, H \& Moradi, 2010, 'Risk-return relationship in Iran stock market', International Research Journal of Finance and Economics, Vol. 41, pp. 10-17.

Yahoo! Finance, 2020, dilihat 11 Maret 2020, https://finance.yahoo.com/quote/^JKLQ45?p=^JKLQ45\&.tsrc=fin-srch

\section{BIBLIOGRAFI}

Diksha P, n.d., Sharpe theory of portfolio management: Financial economics, dilihat 7 Mei 2020, http://www.economicsdiscussion.net/portfolio-management/theories-portfoliomanagement/sharpe-theory-of-portfolio-management-financial-economics/29763

Mandal, N 2013 March, 'Sharpe's Single Index Model and it's application to construct optimal portfolio: An empirical study', Great Lakes Heral, Vol. 7, No. 1. 